\title{
Pengaruh Customer Perceived Value dan Switching Barriers Terhadap Customer Retention
}

\author{
Pipih Sopiyan \\ Program Studi Manajemen FEB Universitas Majalengka \\ pipihoke@gmail.com
}

\begin{abstract}
ABSTRAK
Tujuan dari penelitian ini adalah untuk mengetahui pengaruh Customer Perceived Value dan Switching Barriers Terhadap Customer Retention dengan objek penelitian mahasiswa Universitas Majalengka yang menggunakan Kartu IM3 Ooredoo. Penelitian termasuk jenis penelitian survey dengan pendekatan deskriptif dan verifikatif dengan jumlah sampel digunakan 100 mahasiswa. Sumber data diperoleh dari data primer dimana data diambil secara langsung dari mahasiswa yaitu melalui pengisian kuesioner dengan pengukuran skala likert. Analisis data melalui Analisis Regeresi Berganda, koefisien determinasi, Uji t dan Uji f. Hasil penelitian menunjukan bahwa Customer Perceived Value berpengaruh positif dan signifikan terhadap Customer Retention dengan tingkat kontribusi $21.71 \%$. Switching Barriers berpengaruh positif dan signifikan terhadap Customer Retention dengan tingkat kontribusi sebesar 21.62\%. Customer Perceived Value dan Switching Barriers berpengaruh positif dan signifikan terhadap Customer Retention dengan tingkat kontribusi sebesar $28.8 \%$. Untuk penelitian selanjutnya, penting dilakukan penelitian berkaitan dengan Customer lifetime value dengan 2-3 objek penelitian dan menggunakan alat analisis yang lebih komplek.
\end{abstract}

Kata kunci : Customer Perceived, Switching Barriers, Customer Retention

\begin{abstract}
The purpose of this study was to determine the effect of Customer Perceived Value and Switching Barriers on Customer Retention with the research object of Majalengka University students using IM3 Ooredoo Cards. This research is a type of survey research with descriptive and verification approaches with a sample size of 100 students. The data source was obtained from primary data where data was taken directly from students, namely through filling out a questionnaire with a Likert scale measurement. Data analysis through multiple regression analysis, coefficient of determination, $t$ test and $f$ test. The results showed that Customer Perceived Value has a positive and significant effect on Customer Retention with a contribution rate of $21.71 \%$. Switching Barriers have a positive and significant effect on Customer Retention with a contribution rate of $21.62 \%$. Customer Perceived Value and Switching Barriers have a positive and significant effect on Customer Retention with a contribution rate of $28.8 \%$. For further research, it is important to conduct research related to customer lifetime value with 2-3 research objects and to use more complex analytical tools.
\end{abstract}

Keyword : Customer Perceived, Switching Barriers, Customer Retention

\section{PENDAHULUAN}

Pesatnya perkembangan teknologi informasi saat ini telah memberikan manfaat dalam berbagai aspek kehidupan (Nanda, R., Evanita, S., \& Septrizola, W;207) salah satunya dalam inovasi alat komunikasi seperti smartphone. Saat ini alat komunikasi merupakan kebutuhan manusia yang sangat penting. Sebagai makhluk sosial, penggunaannya sangat membantu komunikasi seseorang untuk selalu terhubung dengan individu lainnya, organisasi dan lingkungan sekitar (Farida, N. 2012:55). Ada beberapa jenis alat komunikasi yang sering digunakan oleh manusia diantaranya radio, televisi, telepon dan smartphone. Smartphone merupakan alat komunikasi terbaru yang perkembangannya sangat pesat dan yang paling sering digunakan oleh manusia saat ini. Berikut data perkembangan penggunaan alat komunikasi :

Tabel 1

Perkembangan Penggunaan Alat Komunikasi pada tahun 2016-2018 (dalam jutaan)

\begin{tabular}{lcccc}
\hline $\begin{array}{c}\text { Alat } \\
\text { Komunikasi }\end{array}$ & $\mathbf{2 0 1 7}$ & $\mathbf{\%}$ & $\mathbf{2 0 1 8}$ & $\boldsymbol{\%}$ \\
\hline Smartphone & 80 & $37,9 \%$ & 98 & $37,5 \%$ \\
\hline Telepon & 62 & $29,4 \%$ & 85 & $32,6 \%$ \\
\hline $\begin{array}{l}\text { Radio \& } \\
\text { Televisi }\end{array}$ & 69 & $32,7 \%$ & 78 & $29,9 \%$ \\
Sumber : Badan Pusat Statistik (BPS) Tahun 2019 &
\end{tabular}


Tingginya penggunaan Smartphone direspon oleh penyedia jasa telekomunikasi (Provider) untuk lebih memahami mengenai upaya untuk mempertahankan pelanggannya dimasa sekarang maupun masa depan (Customer Retention). Customer Retention adalah kecenderungan pelanggan untuk tetap bertahan menggunakan produk atau jasa di masa depan. ini merupakan komitmen konsumen yang timbul dari kesan positif dan rasa puas konsumen atas pembelian produk (Hicks et al, 2005) dalam Cahyono, T. D. (2016:11). Customer retention (retensi pelanggan) sangat penting bagi perusahaan karena semakin tinggi customer retention maka akan semakin banyak profit yang di dapatkan. Mendapatkan customer baru memang penting namun lebih penting lagi untuk bisa mempertahankan customer lama, karena mempertahankan customer lama itu membutuhkan waktu yang lebih cepat dan efektif. lebih mudah mejual kepada customer yang sudah mengenal brand perusahaan daripada menghabiskan waktu untuk mencari customer baru (Danesh et 1, 2012) dalam Hardjanti, A dan Dinna, D, 2014:2).

Berdasarkan hasil penelitian yang telah dilakukan oleh Adiati Hardjati dan Dinna Amalia (2014) serta Yasir (2014) mengemukakan bahwa tinggi rendahnya Customer Retention ditentukan oleh Customer Perceived Value dan switching barriers. Mereka menemukan bahwa Customer Perceived Value dan switching barriers berpengaruh Positif dan Signifikan terhadap Customer Retention pada pelanggan provider internet Speedy atau Fastnet. Dimana nilai yang dirasakan pelanggan semakin baik maka tingkat Customer Retention akan meningkat.

Customer Perceived Value diyakini bahwa nilai yang dipikirkan pelanggan akan memberikan pengaruh terhadap tingkat kepuasan seorang pelanggan terhadap produk atau jasa yang digunakan. Menurut Kotler dan Amstrong (2010:37) dalam Yasir (2014:3) nilai yang dirasakan pelanggan yaitu suatu evalusasi yang dilakukan pelanggan mengenai perbedaan dengan keuntungan yang diperoleh dan biaya yang dikeluarkan, relative dibandingkan dengan tawarantawaran bersaing.

Bagi pelanggan nilai-nilai saja tidak cukup sehingga dikhawatirkan pelanggan yang sebelumnya setia atau loyal menjadi berpindah ke penyedia jasa atau provider yang lain. Perilaku mencari variasi terhadap perpindahan merek menunjukan bahwa nilai pelanggan memiliki pengaruh yang besar terhadap pembelian produk. Pelanggan banyak dipengaruhi oleh beberapa tawaran dari provider atau penyedia jasa seluler dengan tawaran yang beragam, oleh sebab itu pihak perusahaan harus peka terhadap tawaran dari pesaing sehingga hambatan berpindah (Switching barriers) yaitu pelanggan berpindah ke penyedia jasa yang lain. Menurut Jones, et. Al., (2000) dalam Qonitat, N. N., Suyadi, I., \& Sunarti, S (2018:58), Switching Barriers adalah segala faktor yang mempersulit atau memberikan biaya kepada pelanggan jika beralih ke penyedia produk atau jasa yang lain, switching barriers memaksa para pelanggan untuk tetap menggunakan produk atau jasa perusahaannya saat ini. Kemudian menurut (Boateng, Olou \& Ofari, 2014) dalam Nanda, R., Evanita, S., \& Septrizola, W (2019:212) "Hambatan Beralih merupakan kesulitan beralih ke penyedia yang lain, dikarenakan efek beban keuangan, dan psikologis yang dirasakan oleh pelanggan ketika beralih ke jaringan seluler baru". Hal ini menunjukan bahwa switching barriers merupakan faktor yang mempengaruhi keputusan pelanggan untuk tetap menggunakan penyedia jasa yang telah dipilih sebelumnya atau tidak berpindah ke penyedia jasa lain. Hal ini penting karena pelanggan tidak cukup hanya diberikan nilai-nilai pelanggan saja tetapi pelanggan diharapkan memiliki loyalitas pada satu merek tertentu, sehingga perusahaan dapat meningkatkan retensi pelanggan.

Berapa perusahaan penyedia jasa telekomunikasi yang popular di masyarakat Indonesia menurut situs katadata.co.id pada umunya adalah Telkomsel, XL Axiata, Tri, Indosat Ooredoo. Berikut pertumbuhan pelanggan kartu operator seluler di Indonesia pada tahun 2016-2018 :

Tabel 2

Pelanggan Kartu Operator Seluler di Indonesia

Tahun 2016-2018

\begin{tabular}{clccc}
\hline No & Brand SimCard Prabayar & Tahun 2016 & Tahun 2017 & Tahun 2018 \\
\hline 1 & Simpati & $35,5 \%$ & $34,6 \%$ & $39,7 \%$ \\
\hline 2 & IM3 & $15,4 \%$ & $13,6 \%$ & $14,4 \%$ \\
\hline 3 & XL Prabayar & $14,8 \%$ & $13,4 \%$ & $12,7 \%$ \\
\hline 4 & Tri '3' & $11,3 \%$ & $11,4 \%$ & $9,4 \%$ \\
\hline 5 & Kartu As & $10,4 \%$ & $8,6 \%$ & $8,3 \%$ \\
\hline 6 & Axis & $5,1 \%$ & $5,6 \%$ & $6,0 \%$ \\
\hline
\end{tabular}

Sumber :Top Brand Award 
Pelanggan kartu seluler pada tiga tahun terakhir mengalami tren yang menurun. Kecuali pada pengguna kartu Simpati yang mengalami kenaikan. Menurunnya sejumlah pelanggan salah satunya diakibatkan oleh peraturan baru yang membatasi penggunaan kartu seluler yang mengharuskan registrasi menggunakan kartu identitas NIK dan KK. berbagai usaha dilakukan oleh semua provider dalam mempertahankan pelanggannya, sehingga ke depan dipastikan persaingan akan semakin ketat.

Indosat Ooredoo (lengkapnya PT Indosat Tbk., sebelumnya bernama Indosat) yang didirikan pada tahun 1967 dengan kantor pusat di Jalan Medan Merdeka Barat 21, Jakarta Pusat merupakan salah satu perusahaan penyedia jasa telekomunikasi dan jaringan telekomunikasi di Indonesia. Perusahaan ini menawarkan saluran komunikasi untuk pengguna telepon genggam dengan pilihan prabayar maupun pascabayar Indosat, layanan multimedia, internet dan komunikasi data.

Berdasarkan hasil survey kepada 100 mahasiswa Universitas Majalengka diperoleh data bahwa $80 \%$ mereka menggunakan kartu pasca bayar IM3 Ooredoo dengan berbagai alasan dikemukakan diantaranya mengenai harga yang relative lebih murah dibandingkan dengan produk yang lainnya, meskipun signalnya agak sedikit lemah jika disbanding dengan provider Telkomsel. Harga merupakan alasan kuat bagi mereka karena keterbatasan dari keuangan. Harga murah dan mahal juga tergantung dari kerelaan mahasiswa itu sendiri, apakah manfaat yang diperoleh akan lebih besar atau lebih kecil jika dibandingkan dengan biaya yang mereka keluarkan. Namun, jika harganya terlalu mahal akan menjadi hambatan mereka untuk memperolehnya. Jika mereka menilai bahwa produk tersebut memberikan manfaat yang lebih, meskipun harganya dirasakan mahal, tidak menutup kemungkina bagi mereka untuk berusaha memperolehnya, meskipun mereka harus mengeluarkan biaya yang tidak sesuai dengan kemampuan mereka. Alasan ini yang menjadi penting untuk memperoleh data mengenai pengaruh Customer Perceived Value dan Switching Barriers terhadap Customer Retention.

\section{Rumusan Masalah}

Berdasarkan latar belakang di atas penulis merumuskan masalah sebagai berikut :

1. Bagaimana pengaruh Customer Perceived Value terhadap Customer Retention pada mahasiswa Universitas Majalengka pengguna kartu IM3 Ooredoo.

2. Bagaimana pengaruh Switching Barriers terhadap Customer Retention pada mahasiswa Universitas Majalengka pengguna kartu IM3 Ooredoo.
3. Bagaimana pengaruh Customer Perceived Value dan Switching Barriers terhadap Customer Retention pada mahasiswa Universitas Majalengka pengguna kartu IM3 Ooredoo.

\section{Tujuan Penelitian}

Adapun tujuan dari penelitian "Customer Perceived Value dan Switching Barriers Terhadap Customer Retention" adalah sebagai berikut :

1. Untuk mengetahui Pengaruh Customer Perceived Value Terhadap Customer Retention pada mahasiswa Universitas Majalengka pengguna kartu IM3 Ooredoo.

2. Untuk mengetahui Pengaruh Switching Barrierrs Terhadap Customer Retention pada mahasiswa Universitas Majalengka pengguna kartu IM3 Ooredoo.

3. Untuk mengetahui Pengaruh Customer Perceived Value dan Switching Barriers Terhadap Customer Retention pada mahasiswa Universitas Majalengka pengguna kartu IM3 Ooredoo.

\section{KAJIAN PUSTAKA}

\section{Customer Perceived Value}

Nilai yang dirasakan pelanggan (Customer Perceived Value) adalah selisih antara penilaian pelanggan prospektif atas semua manfaat dan biaya dari suatu penawaran terhadap alternatifnya (Kotler \& Keller, 2009) dalam Cahyono, T. D (2016:14). Pelanggan cenderung memaksimalkan nilai dalam batasan biaya pencarian, pengetahuan, mobilitas, dan pendapatan. Pelanggan akan memperkirakan tawaran mana yang dapat memberikan nilai tertinggi yang akan membuat pelanggan bertindak atas dasar pemikiran tersebut. Sesuai atau tidaknya suatu penawaran dengan harapan akan mempengaruhi kepuasan pelanggan dan besarnya probabilitas bahwa pelanggan akan membeli produk itu lagi.

Menurut Parasuraman dan Grewal (2000:169) dalam Astuti, T. (2015 mendefinisikan Perceived Value sebagai suatu konstruk yang terdiri dari empat tipe nilai yaitu acquisition value, transaction value, in-use value, dan redemption value. Acquisition value dijelaskan sebagai keuntungan yang diterima dari harga secara moneter yang telah diberikan. Transaction value sebagai kesenangan yang konsumen terima pada waktu bertransaksi. Inuse value adalah kegunaan yang diberikan pada konsumen atas penggunaan produkdan jasa. Sedangkan redemption value adalah keuntungan residual yang diterima pada waktu produk tidak dipakai lagi. 
Menurut Kotler dan Amstrong (2010:37) dalam Yasir (2014:3) nilai yang dirasakan pelanggan yaitu suatu evalusasi yang dilakukan pelanggan mengenai perbedaan dengan keuntungan yang diperoleh dan biaya yang dikeluarkan, relative dibandingkan dengan tawaran-tawaran bersaing.

Menurut Sweeney dan Sontar (2001) dalam Gantara, G., Kumadji, S., \& Yulianto, E (2013:41) Customer Perceived Value adalah menilai presepsi pelanggan terhadap nilai suatu produk pelanggan tahan lama pada level merek. Skala ini dikembangkan berdasarkan konteks situasi pembelian ritel untuk menentukan nilai-nilai konsumsi yang mengarah pada sikap dan perilaku pembelian.

Dari beberapa definisi di atas, dapat disimpulkan bahwa nilai pelanggan (Customer Perceived Value) adalah nilai yang dirasakan pelanggan didasarkan pada selisih antara apa yang didapatkan pelanggan dan apa yang pelanggan berikan untuk kemungkinan pilihan yang berbeda.

\section{Dimensi Customer Perceived Value}

Perceived Value atau disebut dengan manfaat dari nilai produk yang dirasakan oleh konsumen. Sweeney dan Soutar (2001:214) dalam Andhansari, Putri, et al (2014) dimensi nilai terdiri dari 4 (empat) aspek utama berikut:

1. Emosional Value, yaitu utilitas yang berasal dari perasaan afektif/emosi positif yang ditimbulkan dari mengkonsumsi produk.

2. Social Value, yaitu utilitas yang didapatkan dari kemampuan produk untuk meningkatkan konsep diri-sosial konsumen.

3. Quality/Performance value, adalah utilitas yang didapat dari produk karena reduksi biaya jangka pendek dan biaya jangka panjang.

4. Price/Value of money, yakni utilitas yang diperoleh dari presepsi terhadap kualitas dan kinerja yang diharpkan atas produk.

\section{Switching Barriers (Hambatan Beralih)}

\section{Pengertian Switching Barriers}

Hambatan berpindah (Switching Barriers) merupakan rintangan yang dirasa konsumen untuk beralih dari produk yang lama ke produk baru. Hambatan pindah mengacu pada tingkat kesulitan untuk berpindah ke penyedia jasa lain ketika konsumen tidak puas dengan jasa yang diterima. Hambatan pindah dapat berbentuk kendala finansial, social, dan psikologis yang dirasakan seorang konsumen ketika berpindah ke penyedia jasa baru. Semakin tinggi hambatan pindah, akan semakin mendorong konsumen untuk bertahan dengan penyedia jasa lama.
Menurut Jones, et, al (2000) dalam Qonitat, N. N., Suyadi, I., \& Sunarti, S (2018:58) Switching Barriers adalah segala faktor yang mempersulit atau memberikan biaya kepada pelanggan jika beralih ke penyedia produk atau jasa yang lain, Switching Barriers memaksa para pelanggan untuk tetap menggunakan produk atau jasa perusahannya saat ini.

Menurut (Boateng, Olou \& Ofari, 2014) dalam Nanda, R., Evanita, S., \& Septrizola, W. (2019:212) "Hambatan Beralih merupakan kesulitan beralih ke penyedia yang lain, dikarenakan efek beban keuangan, dan psikologis yang dirasakan oleh pelanggan ketika beralih ke jaringan seluler baru".

Hambatan berpindah adalah hambatan-hambatan atau beban atau biaya yang muncul ketika konsumen akan berpindah dari satu merek ke merek lainnya. Hambatan ini tidak selalu berupa hambatan ekonomis, tetapi bisa juga dapat berkaitan dengan hambatan fungsi, psikologis, social bahkan ritual. Menurut Bansal dan Taylor dalam Farida, N. (2012:59) definisi hambatan berpindah atau Switching Barriers adalah pembebanan konsumen terhadap sumber daya dan kesempatan yang diperlukan bila ia pindah atau pembatas terhadap tindakan untuk pindah.

Dari beberapa definisi diatas, dapat disimpulkan bahwa Switching Barriers adalah hambatan yang dirasakan konsumen bila ia pindah dari satu produk ke produk yang lain. Hambatan ini tidak hanya berdasarkan pertimbangan nilai-nilai ekonomis, melainkan juga berkaitan dengan faktor psikologis, sosial, fungsional, dan ritual.

\section{Dimensi Switching Barriers}

Menurut Jones et al. (2000) dalam Risdianto, G. E (2014) switching barriers adalah segala faktor yang mempersulit atau memberikan biaya kepada pelanggan apabila beralih ke penyedia jasa lain. Ada 3 (tiga) dimensi menurut Jones et al. antara lain:

\section{a. Transaction Cost}

Sejumlah uang yang dikeluarkan oleh pelanggan ketika berganti penyedia jasa sebagai balas jasa.

\section{b. Learning Cost}

Pembelanjaan yang dipandang sebagai proses dimana pengalaman menyebabkan perusahaan dalam pengetahuan, sikap dan atau perilaku. Apabila konsumen beralih dari penyedia jasa maka konsumen harus menyesuaikan diri kembali dengan penyedia jasa baru.

\section{c. Artifical Cost}

Biaya yang berasal dari perusahaan itu sendiri untuk mempertahankan pelanggannya, 
perusahaan memberikan layanan pelengkap yang disesuaikan dengan kebutuhan pelanggan.

\section{Customer Retention}

\section{Pengertian Customer Retention}

Menurut Grifin (2003:5) dalam Wulandari, D.A (2014:28) menjelaskan bahwa Customer Retention adalah lamanya hubungan dengan pelanggan. Tingkat customer retention adalah persentase pelanggan yang telah memenuhi sejumlah pembelian ulang selama periode waktu terbatas.

Dalam upaya mempertahan pelanggan, perusahaan memerlukan adanya loyalitas dari pelanggan, namun sikap loyal saja tidak cukup untuk menjamin keberlangsungan hidup perusahaan, diperlukan adanya tindakan nyata sebagai bukti bahwa pelanggan benar-benar loyal terhadap perusahaan, yaitu adanya Customer Retention. customer retention adalah kecenderungan Pelanggan untuk tetap bertahan dalam menggunakan suatu produk atau jasa setelah pelanggan merasakan adanya kepuasan yang diperoleh dalam menggunakan produk tersebut (Ranawera dan Prabhu 2003) dalam Qonitat, N. N., Suyadi, I., \& Sunarti, S. (2018:59).

Menurut Tjiptono (2006:1) dalam Qonitat, N. N., Suyadi, I., \& Sunarti, S. (2018:59) ketatnya persaingan menyebabkan kejenuhan pasasr, jika perusahaan terus menerus mencari pelanggan baru yang akan menggantikan pelanggan lama, perusahaan tidak akan mencapai tujuan tertentu seperti eksistensi, mencapai pertumbuhan, merebut pangsa pasar, dan lain-lain. Perlu ada tindakan nyata sebagai bukti bahwa pelanggan benar-benar loyal terhadap peusahaan, yaitu dengan adanya Customer Retention. Pelanggan akan tetap bertahan dalam menggunakan suatu produk atau jasa setelah pelanggan merasakan adanya kepuasan yang diperoleh dalam menggunakan produk tersebut.

Customer retention merupakan bentuk loyalitas yang berhubungan dengan perilaku yang diukur berdasarkan perilaku beli konsumen yang ditunjukan tingginya frekuensi konsumen membeli suatu suatu produk. Sementara itu loyalitas sendiri lebih mengacu pada sikap ukur berdasarkan komponen-komponen sikap, keyakinan, perasaan, dan kehendak untuk melakukan pembelian (Buttle, 2004) dalam Wulandari, D.A (2014:29).

Dari beberapat definisi diatas dapat disimpulkan bahwa Customer Retension adalah tentang bagaimana caranya perusahaan mempertahankan pelanggan lama agar tetap setia untuk membeli kembali produk atau jasa tersebut dan tidak berpindah ke produk atau jasa yang baru berdasarkan.

\section{Dimensi Customer Retention}

Menurut Kotler (dalam Aurelia, G. S., Ramdan, A. M., \& Samsudin, A. (2019). (2019:14) ada tiga Dimensi untuk membangun customer retention (retensi pelanggan) :

1. Financial Benefit (manfaat finansial). Retensi pelanggan memberikan keuntungan terhadap perusahaan, hal tersebut karena adanya pembelian yang berulang, serta adanya pembentukan kelompok pelanggan dengan perusahaan dan adanya pemberian penghargaan bagi pelanggan dan perusahaan.

2. Sosial Benefit (manfaat sosial). Membentuk hubungan secara pribadi antara pegawai perusahaan dengan pelanggan dalam menciptakan hubungan jangka panjang dan membangun relasi dengan masing-masing pelanggan secara pribadi.

3. Structural Ties (Ikatan Struktural). Suatu ikatan structural dimana terbentuk komitmen pada hubungan antara pelanggan dengan perusahaan sehingga tercipta hubungan jangka panjang diantara keduanya.

\section{Hubungan Antar Variabel}

\section{Hubungan Customer Perceived Value Terhadap Customer Retention}

Customer Perceived Value adalah nilai yang dirasakan pelanggan didasarkan pada selisih antara apa yang didapatkan pelanggan dan apa yang pelanggan berikan untuk kemungkinan pilihan yang berbeda. Perceived Value merupakan penilaian tentang nilai yang dirasakan oleh pelanggan, yang diantaranya mencakup kesesuaian harga dan kualitas, reputasi merek dan manfaat dari nilai yang dibayarkan, kesesuaian harga dan kualitas akan memberikan kepuasan kepada pelanggan karena biaya yang dikeluarkan sesuai dengan manfaat yang diterima. Reputasi merek akan tercipta ketika pelanggan merasa puas dengan produk atau jasa yang sudah digunakan dan sesuai dengan harapan pelanggan, sehinggan implikasi nya akan berdampak kepada Customer Retention.

Berdasarkan hasil penelitian yang telah dilakukan oleh Hardjanti, A dan Dinna, D. (2014) mengemukakan bahwa Customer Perceived Value berpengaruh Positif dan Signifikan terhadap Customer Retention pada pelanggan provider internet Speedy atau Fastnet. Dimana nilai yang dirasakan pelanggan semakin baik maka tingkat Customer Retention akan meningkat. Dan Yasir (2014) juga menyimpulkan hal yang sama dalam penelitiannya pada pengguna Samsung Android di Surabaya bahwa Nilai yang Dirasa (Customer Perceived Value) berpengaruh positif dan signifikan terhadap Retensi Pelanggan (Customer Retention). 


\section{Hubungan Switching Barriers Terhadap Customer Retention}

Switching Barriers adalah hambatan yang dirasakan konsumen bila ia pindah dari satu produk ke produk yang lain. Switching Barriers mewakili faktor apapun yang membuatnya lebih sulit atau mahal bagi konsumen untuk mengubah penyedia layanan saat ini sehingga membuat konsumen melakukan konsumsi yang berkelanjutan dan dalam jangka waktu yang panjang. Maka dari itu akan membantu perusahaan untuk mencegah pelanggan beralih produk dan tetap setia terhadap produk perusahaan dengan menciptakan hambatan bagi pelanggan untuk beralih produk.

Berdasarkan dari hasil penelitian yang telah dilakukan oleh Hardjanti, A dan Dinna, D. (2014) bahwa Switching Barriers berpengaruh positif dan signipikan terhadap Customer Retention. Semakin tinggi hambatan pindah (switching barriers), akan semakin mendorong konsumen untuk bertahan dengan penyedia jasa lama. Hasil penelitian yang dilakukan oleh Yasir (2014), Nanda, R., Evanita, S., \& Septrizola, W (2019), Qonitat, N. N., Suyadi, I., \& Sunarti, S. (2018), dan Puspita, A. I., Abdillah, Y., \& Bafadhal, A. S. (2018) memperlihatkan Bahwa Hambata Beralih (Switching Barriers) berpengaruh positif dan signifikan terhadap Customer Retention.

Hubungan Customer Perceived Value dan Switching Barriers Terhadap Customer Retention

Mengacu pada penjelasan Hipotesis sebelumnya, yaitu diasumsikan bahwa Customer Perceived Value mempunyai hubungan Customer Retention, dan Switchi Barriers juga mempunyai hubungan dengan Customer retention. Hal ini menunjukan bahwa semakin tinggi tingkat Customer Perceived Value dan Switching Barriers maka semakin tinggi pula tingkat Customer Retention.

Berdasarkan penelitian yang telah dilakukan oleh Hardjanti, A dan Dinna, D. (2014) menunjukan bahwa Customer Perceived Value dan Switching Barriers berpengaruh positif dan signifikan terhadap Customer Retention pada pada pelanggan provider internet Speedy atau Fastnet. Hal ini dibuktikan pada konsumen yang telah berlanggan minimal 6 bulan lamanya. Hasil menujukan bahwa pelanggan akan tetap setia kepada produk atau jasa yang digunakannya jika nilai yang dirasa sebanding dengan apa yang pelanggan berikan untuk perusahann. Setelah pelanggan merasa puas maka hambatan untuk berpindah ke produk atau jasa lain akan sulit dilakukan. Dengan demikian, bahwa variabel Customer Perceived Value dan Switching Barriers dapat mempengaruhi Customer Retention secara simultan.
Customer Retention adalah kecenderungan Pelanggan untuk tetap bertahan dalam menggunakan suatu produk atau jasa setelah pelanggan merasakan adanya kepuasan yang diperoleh dalam menggunakan produk tersebut. (Ranawera dan Prabhu 2003) dalam Qonitat, N. N., Suyadi, I., \& Sunarti, S. (2018:59). Customer Retention (retensi pelanggan) sangat penting bagi perusahaan karena semakin tinggi Customer Retention maka akan semakin banyak profit yang di dapatkan. Karena biaya yang dibutuhkan untuk mencari customer baru lima kali lebih banyak dari pada mempertahankan customer lama. Dan juga mempertahan kan customer lama itu membutuhkan waktu yang lebih cepat dan eefektif dibandingkan dengan mencari customer baru. Dalam penelitian ini Customer Retention menggunakan Dimensi dari Kotler (dalam Risdianto, G. E (2019:14) yaitu Financial Benefit (manfaat finansial), Sosial Benefit (manfaat sosial), dan Structural Ties (Ikatan Struktural).

Menurut Kotler dan Amstrong (2010:37) dalam Yasir (2014:3) nilai yang dirasakan pelanggan (customer perceived value) yaitu suatu evalusasi yang dilakukan pelanggan mengenai perbedaan dengan keuntungan yang diperoleh dan biaya yang dikeluarkan, relative dibandingkan dengan tawarantawaran bersaing. Nilai yang dirasakan pelanggan didasarkan pada selisih antara apa yang didapatkan pelanggan dan apa yang pelanggan berikan untuk kemungkinan pilihan yang berbeda. Perusahaan atau penyedia jasa telah memberikan beberapa nilai pelanggan untuk memenuhi kebutuhan dari pelanggan. Jika pelanggan sudah merasa puas akan nilai yang dirasakannya maka pelanggan akan tetap setia dan enggan untuk beralih ke penyedia jasa lain. Dalam penelitian ini customer perceived value menggunakan dimesi dari Sweeney dan Soutar (2001:214) dalam Astuti, T. (2015) dimensi nilai terdiri dari 4 (empat) aspek uatama yaitu : Emosional Value, Social Value, Quality/Performance value, dan Price/Value of money.

Menurut Jones, et, al (2000) dalam Qonitat, N. N., Suyadi, I., \& Sunarti, S. (2018:58) Switching Barrier adalah segala faktor yang mempersulit atau memberikan biaya kepada pelanggan jika beralih ke penyedia produk atau jasa yang lain, Switching Barrierrs memaksa para pelanggan untuk tetap menggunakan produk atau jasa perusahannya saat ini. Hambatan beralih mengacu pada tingkat kesulitan untuk berpindah ke penyedia jasa lain ketika konsumen tidak puas dengan jasa yang diterima. Semakin tinggi hambatan beralih, maka akan semakin mendorong konsumen untuk tetap bertahan dengan penyedia jasa lama. Dalam penelitian ini switching barriers menggunakan dimensi dari Menurut Jones et al. (2000) dalam 
Risdianto, G. E. (2014) Ada 3 (tiga) dimensi menurut Jones et al. antara lain: Transaction Cost, Learning Cost, dan Artifical Cost.Dengan adanya customer perceived value dan switching barriers apabila dilakukan secara bersama-sama maka diduga mampu meningkatkan pelanggan untuk tetap setia pada produk atau jasa yang sedang digunakan. Semakin tinggi tingkat customer perceived value dan switching barriers pada suatu perusahaan maka tingkat customer retention akan semakin meningkat dan tetap bertahan pada perusahaan tersebut.Customer Perceived value dan Switching Barriers serta Customer Retention adalah bagaimana cara nya perusahaan mempertahankan pelanggan melalui nilai yang dirasakan pelanggan terhadap produk atau jasa yang digunakan sehingga pelanggan merasakan kesulitan untuk berpindah ke produk atau jasa yang lain sehingga pelanggan untuk tetap bertahan dalam menggunakan suatu produk atau jasa.

\section{METODE PENELITIAN}

Metode yang digunakan dalam penelitian ini adalah metode survei dengan pendekatan analisis deskriptif dan analisis verifikatif. Populasi dalam penelitian adalah mahasiswa Universitas Majalengka yang berjumlah 100 orang sebagai sampel. Jenis data yang digunakan dalam penelitian ini yaitu data kualitatif yang dikuantitatifkan. Sumber data diperoleh dari data primer dimana data yang diambil secara langsung dari responden yaitu melalui pengisian kuesioner. Kuesioner yang disebarkan sebanyak 19 pernyataan (7 pernyataan untuk Customer Perceived Value, 6 pernyataan mengenai Switching Barriers dan 6 pernyataan untuk Customer Retention). Cara menilai jawaban dari setiap kuesioner melalui sikap responden dengan skala skala likert. Pengujian instrumen penelitian dilakukan dengan Uji Validitas dan Reliabilitas. Selanjutnya dilakukan konversi dari data berskala ordinal ke data berskala interval dengan Method of Successive Interval(MSI) kemudian dilakukan Uji Normalitas Data. Analisis data yang digunakan melalui Analisis Regeresi Berganda, koefisien determinasi, Uji t dan Uji f.

\section{HASIL PENELITIAN DAN PEMBAHASAN}

\section{Profil Responden}

Pembahasan ini bertujuan untuk menggambarkan karakteristik demografi dari 100 orang responden yang dijadikan sampel pada penelitian ini. Karakteristik demografi tersebut adalah sebagai berikut:
Tabel 3 Profil Responden

\begin{tabular}{clcc}
\hline No & Karakteristik & Jumlah & $\%$ \\
\hline 1 & Laki - Laki & 48 & $48 \%$ \\
2 & Perempuan & 52 & $52 \%$ \\
3 & $18-21$ tahun & 37 & $37 \%$ \\
4 & $22-25$ tahun & 60 & $60 \%$ \\
5 & $>25$ tahun & 3 & $3 \%$ \\
6 & $>55$ tahun & 2 & 1
\end{tabular}

(Sumber : Data Tabulasi Penelitian Tahun 2020)

Berdasarkan table 3 di atas menunjukan bahwa responden yang digunakan dalam penelitian ini mayoritas berjenis kelamin perempuan dan mereka kebanyakan berada dalam rentang usia 22-25 tahun.

\section{Hasil Tanggapan Customer Perceived Value}

Pengukuran Customer Perceived Value dilakukan dengan memberikan 7 pernyataan kepada responden dengan rekapitulasi sebagai berikut :

Tabel 4 Rekapitulasi Jumlah Skor Tanggapan Responden Terhadap Customer Perceived Value

\begin{tabular}{clc}
\hline No. & \multicolumn{1}{c}{ Pernyataan } & $\begin{array}{c}\text { Jumlah } \\
\text { Skor }\end{array}$ \\
\hline 1 & $\begin{array}{l}\text { Saya merasa nyaman } \\
\text { menggunakan kartu IM3 Ooredoo }\end{array}$ & 414 \\
2 & $\begin{array}{l}\text { Kualitas pelayanan kartu IM3 } \\
\text { Ooredoo tidak mengecewakan } \\
\text { Saya merasa percaya diri } \\
\text { menggunakan kartu IM3 Ooredoo }\end{array}$ & 407 \\
4 & $\begin{array}{l}\text { Harga kartu IM3 Ooredoo sesuai } \\
\text { dengan kualitas layanan yang } \\
\text { diberikan }\end{array}$ & 411 \\
Harga kartu IM3 Ooredoo sesuai \\
dengan manfaat yang diharpkan \\
oleh pelanggan.
\end{tabular}

Berdasarkan tabel 4 di atas diperoleh jumlah skor sebesar 2.970 atau $84.86 \%$ mahasiswa memberikan Perceived Value yang sangat baik dari penggunaan kartu IM3 Ooredoo. Kondisi tersebut terlihat dari kenyamanan yang diperoleh, kualitas pelayanan yang tidak mengecewakan dan harga produk yang dirasa telah.sesuai dengan manfaat dan kemampuan mahasiswa.

\section{Hasil Tanggapan Switching Barriers}

Pengukuran Switching Barriers dilakukan dengan memberikan 6 pernyataan kepada responden dengan rekapitulasi sebagai berikut : 
Tabel 5

Rekapitulasi Jumlah Skor Tanggapan Responden Terhadap Switching Barriers

\begin{tabular}{clc}
\hline No. & \multicolumn{1}{c}{ Pernyataan } & $\begin{array}{c}\text { Jumlah } \\
\text { Skor }\end{array}$ \\
\hline 1 & $\begin{array}{l}\text { Bila saya berpindah ke produk lain } \\
\text { maka akan mengeluarkan biaya yang } \\
\text { lebih mahal. }\end{array}$ & 431 \\
2 & $\begin{array}{l}\text { Harga produk lain lebih mahal dari } \\
\text { pada kartu IM3 Ooredoo } \\
\text { Membutuhkan banyak usaha dan } \\
\text { tenaga jika berpindah ke produk lain. }\end{array}$ & 407 \\
4 & $\begin{array}{l}\text { Harus menyesuaikan kembali dengan } \\
\text { produk baru jika igin bepindah. }\end{array}$ & 425 \\
Pelayanan yang diberikan kartu IM3 \\
Ooredo sesuai dengan kebutuhan \\
mahasiswa. \\
$\begin{array}{l}\text { Saya merasa nyaman dan puas saat } \\
\text { menggunakan Kartu IM3 Ooredoo. }\end{array}$ & 429 \\
\multicolumn{3}{c}{ Jumlah } \\
\hline Skor maksimum yang seharusnya tercapai \\
(Skor Maksimal 5 x 6 butir Pernyataan x \\
$\quad$ Persentase
\end{tabular}

Berdasarkan tabel 3 diperoleh jumlah skor sebesar 2.498 atau $83.27 \%$. Hal ini menunjukan bahwa tingginya Switching Barriers pada mahasiswa dalam menggunaan kartu IM3 Ooredoo. Mahasiswa beranggapan jika mereka bepindah menggunakan produk lain, maka akan banyak pengorbanan dikeluarkan baik secara materi maupun non materi.

\section{Hasil Tanggapan Customer Retention}

Pengukuran Customer Retention dilakukan dengan memberikan 6 pernyataan kepada responden dengan rekapitulasi sebagai berikut :

\section{Tabel 6}

Rekapitulasi Jumlah Skor Tanggapan Responden Terhadap Customer Retention

\begin{tabular}{clc}
\hline No & \multicolumn{1}{c}{ Pernyataan } & $\begin{array}{c}\text { Jumlah } \\
\text { Skor }\end{array}$ \\
\hline 1 & $\begin{array}{l}\text { Saya akan melakukan pembelian ulang } \\
\text { pada produk kartu IM3 ooredoo }\end{array}$ & 429 \\
2 & $\begin{array}{l}\text { Saya lebih mengutamakan menggunakan } \\
\text { kartu IM3 Ooredoo. } \\
\text { Memberitahu kepada orang-orang tentang } \\
\text { manfaat produk IM3 Ooredoo }\end{array}$ & 418 \\
Menjadi pelanggan IM3 Ooredoo memiliki \\
rasa prestise tersendiri karena perusahaan \\
$\begin{array}{l}\text { yang banyak diminati akan pelayanannya. } \\
\text { Saya menjadi pelanggan yang loyal pada } \\
\text { produk IM3 Ooredoo. }\end{array}$ & 408 \\
Saya mearasa bangga menjadi pelanggan \\
yang setia terhadap IM3 Ooredoo
\end{tabular}

Berdasarkan tabel 4 diperoleh jumlah skor sebesar 2.494 atau $83.13 \%$. hal ini menunjukan bahwa tingginya Customer Retention mahasiswa dalam menggunakan kartu IM3. Mereka loyal dan bangga menggunakan produk tersebut, mereka bersedia untuk selalu pembelian ulang dan selalu menggunakan produknya serta mereka juga bersedia untuk merekomendasikan kepada orang lain bahwa produk tersebut memberikan manfaat yang lebih jika dibandingkan dengan produk lainnya.

Pengaruh Shopping Lifestyle dan Positive Emotion Terhadap Impuls Buying

Hasil pengolahan diperoleh dengan menggunakan software SPSS 21 adalah sebagai berikut:

Tabel 7 Hasil Analisis Regresi Linier Berganda

\begin{tabular}{|c|c|c|c|c|c|c|c|}
\hline & \multicolumn{7}{|c|}{ Coefficients $^{\mathrm{a}}$} \\
\hline \multirow{2}{*}{\multicolumn{2}{|c|}{ Model }} & \multicolumn{2}{|c|}{$\begin{array}{l}\text { Unstandardized } \\
\text { Coefficients }\end{array}$} & $\begin{array}{c}\text { Standardized } \\
\text { Coefficients }\end{array}$ & $\mathrm{t}$ & Sig. & Correlations \\
\hline & & B & Std. Error & Beta & & & $\begin{array}{l}\text { Zero- Parti Part } \\
\text { order al }\end{array}$ \\
\hline & (Constant) & 805.863 & 211.931 & & 3.802 & .000 & \\
\hline \multirow[t]{2}{*}{1} & $\mathrm{X} 1$ & .297 & .094 & .311 & 3.143 & .002 & $.304 \quad 269$ \\
\hline & $\mathrm{X} 2$ & .335 & .107 & .309 & 3.127 & .002 & $\begin{array}{lll}.465 & .303 & .268\end{array}$ \\
\hline
\end{tabular}

a. Dependent Variable: $Y$

Tabel 8 Hasil Koefisien Deteminasi Secara Simultan

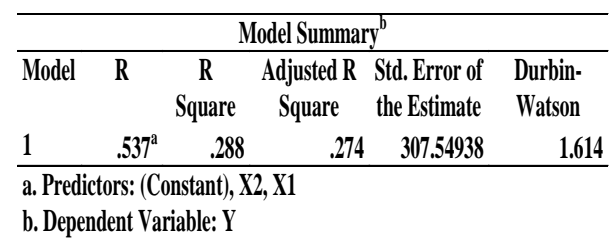

Tabel 9 Hasil Uji Hipotesis Secara Simultan

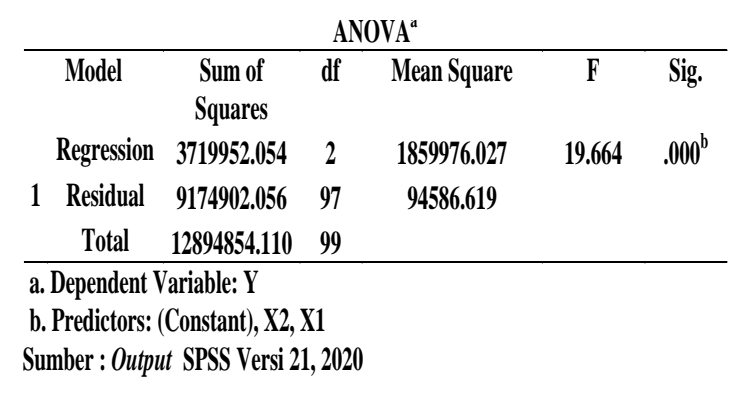

Berdasarkan tabel 9 menunjukan bahwa persamaan regresi linear berganda yang diperoleh dari hasil analisis yaitu $\mathrm{Y}=805.863+0,297 \mathrm{X}_{1}+0.335 \mathrm{X}_{2}$ maka dari persamaan di atas dapat diartikan sebagai berikut :

1. Konstanta $(\alpha)$ dalam regresi sebesar 805.863 dan bertanda positif artinya Customer Retention 
bernilai 805.863 tanpa adanya pengaruh dari Customer Perceived Value dan Switching Barriers.

2. Koefisien regresi Customer Perceived Value sebesar 0.297 dan bertanda positif, artinya setiap penambahan satu aktivitas Customer Perceived Value akan meningkatkan Customer Retention sebesar 0.297

3. Koefisien regresi Switching Barriers 0.335 dan bertanda positif, artinya setiap penambahan satu aktivitas Switching Barriers, maka akan meningkatkan Customer Retention sebesar 0.335

Berdasarkan tabel 5 dilihat dari kolom Zero-Order, nilai koefisiennya 0.466 artinya besarnya kontribusi Customer Perceived Value mempengaruhi Customer Retention yaitu sebesar $21.71 \%$. Meskipun nilai kontribusinya kecil namun nilai ini cukup berarti bagi peningkatan Customer Retention. Artinya jika semakin baik Customer Perceived Value, maka akan meningkatkan Customer Retention. Hasil penelitian ini mendukung penelitian Hardjanti, A dan Dinna, D. (2014), yang menyatakan bahwa Customer Perceived Value berpengaruh positif dan signifikan terhadap Customer Retention.

Sementara pengaruh Switching Barriers terhadap Customer Retention diperoleh nilai koefisien sebesar 0.465. Artinya besar kontribusi dari Switching Barriers hanya $21.62 \%$. Kontribusinya lebih kecil dari Customer Perceived Value. Namun nilai ini cukup berarti untuk meningkatkan Customer Retention. Hasil penelitian ini mendukung dengan penelitian yang dilakukan oleh Yasir (2014), Qonitat, N. N., Suyadi, I., \& Sunarti, S. (2018), Puspita, A. I., Abdillah, Y., \& Bafadhal, A. S. (2018) Nanda, R., Evanita, S., \& Septrizola, W (2019), yang menyatakan bahwa Switching Barriers berpengaruh positif dan signifikan terhadap Customer Retention.

Secara simultan berdasarkan pada tabel 6 dan 7 diatas diperoleh bahwa Customer Perceived Value dan Switching Barriers berpengaruh terhadap Customer Retention yakni sebesar $28.8 \%$. Artinya bahwa jika seseorang memiliki Customer Perceived Valued yang baik dan Switching Barriers yang tinggi dari penggunaan suatu produk, maka akan meningkatkan Customer Retention . Berdasarkan hasil penelitian yang diperoleh, peneliti melihat bahwa tingginya Customer Retention akan dipengaruhi oleh banyak faktor. Sehingga sangat penting dan perlu adanya penelitian kembali dengan menambah variabel lainnya sebagai inductor,

\section{SIMPULAN DAN SARAN}

\section{Simpulan}

Berdasarkan hasil penelitian yang telah dilakukan, maka dapat diambil kesimpulan sebagai berikut:

1. Customer Perceived Value berpengaruh positif dan signifikan terhadap Customer Retention dengan tingkat kontribusi $21.71 \%$. Artinya semakin baik Customer Perceived Value, maka akan meningkatkan Customer Retention.

2. Switching Barriers berpengaruh positif dan signifikan terhadap Customer Retention dengan tingkat kontribusi sebesar $21.62 \%$. Artinya Semakin tinggi Switching Barriers, maka akan meningkatkan Customer Retention

3. Customer Perceived Value dan Switching Barriers berpengaruh positif dan signifikan terhadap Customer Retention dengan tingkat kontribusi sebesar $28.8 \%$. Artinya jika semakin baik Customer Perceived Value dan semakin tingginya Switching Barriers, maka akan meningkatkan Customer Retention.

\section{Saran}

Berdasarkan kesimpulan hasil penelitian yang diperoleh di atas, maka beberapa saran yang dapat diberikan sebagai berikut :

1. Melihat tingginya persaingan bisnis dalam bidang telekomunikasi, saatnya perusahaan berpikir dalam meningkatkan Customer Retention melalui Customer Perceived Value dan Switching Barriers. Perusahaan harus mampu selalu berinovasi baik dalam produk maupun layanan. Produk yang selalu dipersepsikan baik dan memiliki Switching Barriers yang tinggi menjadi salah satu kunci untuk meningkatkan Customer Retention. Perusahaan harus selalu melakukan evaluasi dan riset pasar untuk mengetahui keinginan dan kebutuhan pasar. Sehingga strategi pemasaran produk akan selalu up to date. Selanjutnya, penting untuk selalu menjaga kualitas signal satelit, ini yang pertama dikeluhkan oleh mahasiswa disamping harga dari produk.

2. Ruang lingkup penelitian ini masih terbatas, terletak pada 2 variabel independen, 1 objek penelitian dan alat analisis yang digunakan masih sederhana. Untuk penelitian selanjutnya kiranya masih sangat perlu adanya penelitian kembali dengan ruang lingkup yang lebih luas seperti pada penambahan variabel independen seperti Customer lifetime value, 2-3 objek penelitian dan menggunakan alat analisis yang lebih komplek. 


\section{DAFTAR PUSTAKA}

Andhansari, Putri, et al. 2014 "Pengaruh Kualitas Pelayanan dan Nilai Pelanggan terhadap Kepuasan Pelanggan (Studi Kasus pada Penumpang Bus PO. Haryanto Kudus)." Jurnal Ilmu Administrasi Bisnis S1 Undip, vol. 3, no. 2, 2014, pp. 152-162.

Astuti, T. (2015). pengaruh persepsi konsumen pada keputusan pembelian (Doctoral dissertation, Universitas Muhammadiyah Surakarta).

Aurelia, G. S., Ramdan, A. M., \& Samsudin, A. (2019). Analisis Customer Satisfaction dan Brand Trust terhadap Customer Retention. JOMB: Journal of Management and Bussines, l(1), 10-21.

Cahyono, T. D. (2016). Analisis Pengaruh Persepsi Kualitas dan Persepsi Nilai Terhadap Kepuasan Konsumen dan Minat Beli Ulang. Jurnal Tambora, 1(3).

Farida, N. (2012). Pengaruh Nilai Pelanggan Dan Hambatan Berpindah Terhadap Loyalitas Pelanggan Serta Implikasi Pada Perpindahan Merek Studi Pada Mahasiswa Fisip Undip Semarang Pengguna Kartu Prabayar Im3 PT. Indosat Tbk. Jurnal Administrasi Bisnis, 1(1), $55-64$

Gantara, G., Kumadji, S., \& Yulianto, E. (2013). Analisis pengaruh kualitas layanan dan perceived value terhadap kepuasan pelanggan dan loyalitas pelanggan. Jurnal Administrasi Bisnis, 1(1), 40-48.

Hardjanti, A dan Dinna, D. 2014. "Pengaruh Customer Services Quality, Customer Perceived Value, Customer Satisfaction, Customer Trust Dan Switching Barriers Terhadap Customer Retention". Jurnal Ekonomi. Universitas Trisakti Jakarta. Vol.5, No.1, Mei 2014: 1-12

Nanda, R., Evanita, S., \& Septrizola, W. (2019). Pengaruh Kepuasan Pelanggan, Hambatan Beralih, dan Kepercayaan Pelanggan tehadap Retensi Pelanggan Pengguna Kartu Simpati pada Mahasiswa Universitas Negeri Padang (Doctoral dissertation, Universitas Negeri Padang)

Puspita, A. I., Abdillah, Y., \& Bafadhal, A. S. (2018). Pengaruh Customer Satisfaction Terhadap Switching Barriers dan Customer Retention (Survei Online pada Konsumen Produk Kosmetik

L'Oréal Paris di Indonesia dan China). Jurnal Administrasi Bisnis, 61(1), 153-162.
Qonitat, N. N., Suyadi, I., \& Sunarti, S. (2018). Pengaruh Kepuasan Pelanggan, Switching Barrier Dan Kepercayaan Merek Terhadap Customer Retention (Survei pada Mahasiswa S1 Universits Brawijaya Malang Pelanggan Produk Merek Wardah). Jurnal Administrasi Bisnis, 55(2), 57-67.

Risdianto, G. E. (2014). Pengaruh Customer Satisfaction dan Switching Barriers terhadap Customer Loyalty dengan menggunakan Variabel Customer Trust sebagai Variabel Moderating pada Toko Buku Petra Togamas Surabaya. Jurnal Strategi Pemasaran, 2(2), 110.

Wulandari, D.A. 2014. "Pengaruh Switching Barriers terhadap Customer Retention pada Nasabah Bank BCA cabang Kuntoarjo”. Purworejo. Skripsi. Universitas Muhammadiyah.

Yasir. 2014. "Pengaruh Kepercayaan Pelanggan, Nilai Yang Dirasa, Dan Hambatan Beralih Terhadap Retensi Pelanggan Pada Pengguna Samsung Android Di Surabaya”. Artikel Ilmiah. STIE Perbanas Surabaya. 